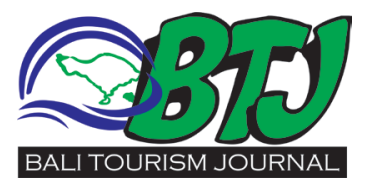

\section{Balinese' perspective in Myths and Diseases: How the society copes and survive the situation}

\author{
Yogi Meranggi ${ }^{1}$
}

'PT. PLN (Persero) Area Bali Timur; yogimerangqi@gmail.com

Editor:

Ida Bagus Ngurah Tri Pramana
Received : 2020-02-15 Accepted : 2020-03-05 Published: $2020-04-28$

\section{BACKGROUND}

Since the ancient period, human has been developing their communication skills to transfer a message from one individual to others, then for broader means. The ability allows Homo sapiens to cooperate on a larger scale and to achieve what a single human could not obtain. Broadscale cooperation could be done due to complex communication that gave birth to fiction and Myth. ${ }^{1}$ The rise of fiction and Myth on humankind enables more than a hundred individuals without prior acquaintanceship work in harmonic cooperation. It shapes what we addressed as culture nowadays. A belief system, according to Koentjaraningrat's cultural system concept ${ }^{2}$ consists of dozens myths and fictions. The story acts as media of learning about the way of life, ideology, philosophy and moral value. A legacy of forefather to their future offspring. It may as well offers consultation about a various event in the past. Should in future the descendant faced grave danger, the ancient wisdom would be at their disposal to consult or to seek an answer.

\section{MYTHS AND DISEASES}

Myths are common in Balinese society' belief system that rooted back to the local religion, Wali many unfortunate situations, including plagues and diseases. The mythical story leads to numerous ceremonies being celebrated on the island. The ritual act as an expression of gratitude, apologise, and a moment to self-reflect that humankind is not the only creature that inhabits the universe. The teaching emphasises that the local community is mandatory to take care of their environment, avoid exploiting nature, subsequently as an alarm to the individual to live in humble and responsible. Despite the locals are well adapted to modern technology and received higher education, apparently did not halt the rites. They believed the activities are identity as well as precious treasure from their honourable ancestor.

Keyword: Myths, Diseases, Balinese

Cite This Article: Meranggi, Y. Balinese' perspective in Myths and Diseases: How the society copes and survive the situation. Bali Tourism Journal (BTJ) 2020, 4(1): 14-18. D0I : 10.36675/btj.v4i1.41

and Hinduism teaching. There are many stories in ancient texts; most of them cover the story of influential figures such as Gods, Deities, Demon, evil spirit and et cetera. Gods and Goddess represent good, righteousness and source that brings happiness and joy to human. Whereas other entities like Demons and evil spirits become a symbol of maleficent that create chaos and disaster on earth. ${ }^{4}$ Besides stories of good and evil, the text also discusses multiple important events in the past, history of rituals, catalogue of arts, medicines, even ancient wisdom that relatable to the current situation. The text is commonly written on Borassus leaf called Lontar. The community put great respect on the text and even considered it a sacred object. Therefore, it is understandable that in Balinese civilisation' mindset, an ancient text on Lontar became the only source of the answer in overcoming problems that were faced by the people.

Through Balinese history, there were many disasters, plagues, and diseases that took heavy tolls. ${ }^{5}$ Some text would suggest the people conduct a ritual to ask powerful deities to put an end to the calamity. For instance, in the year 1246, as mentioned in stone tablet Jiken Sastra, the King and his people were requested to worship Bhatara I Kusumadanta to drive away from unstoppable diseases that lingered on their country over the 


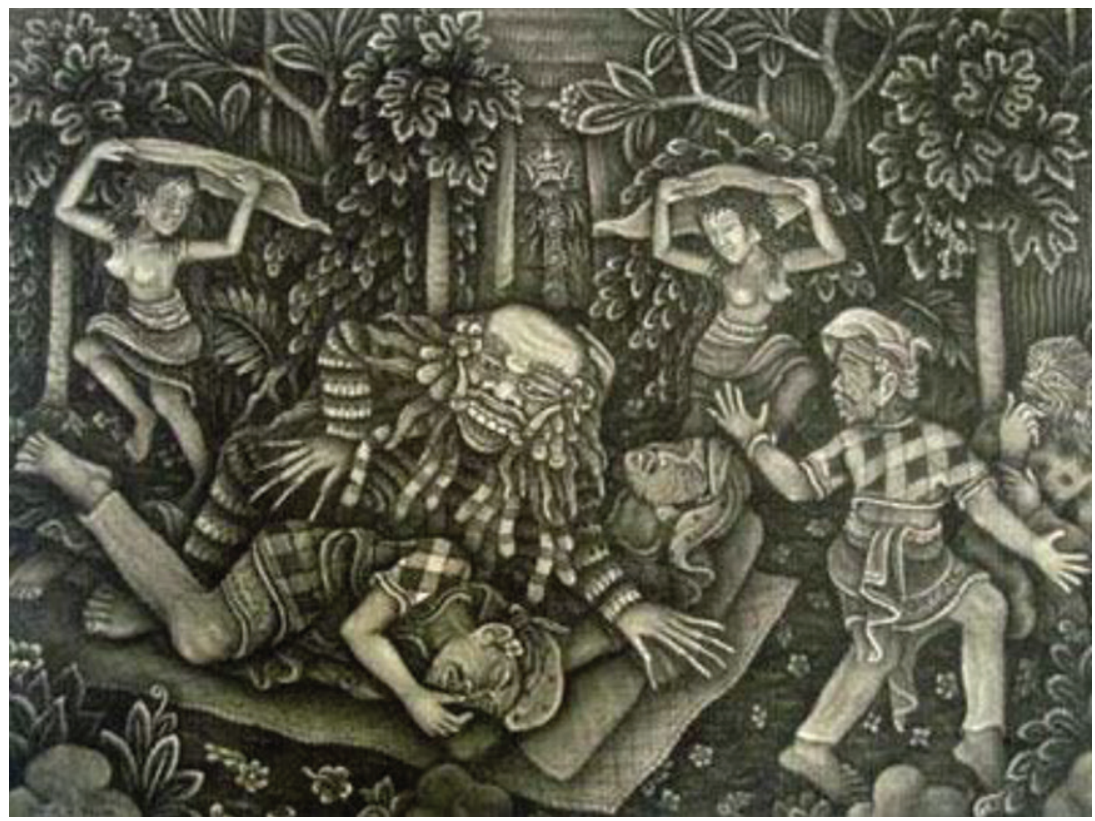

Figure 1. Illustration of Evil spirit causing sickness

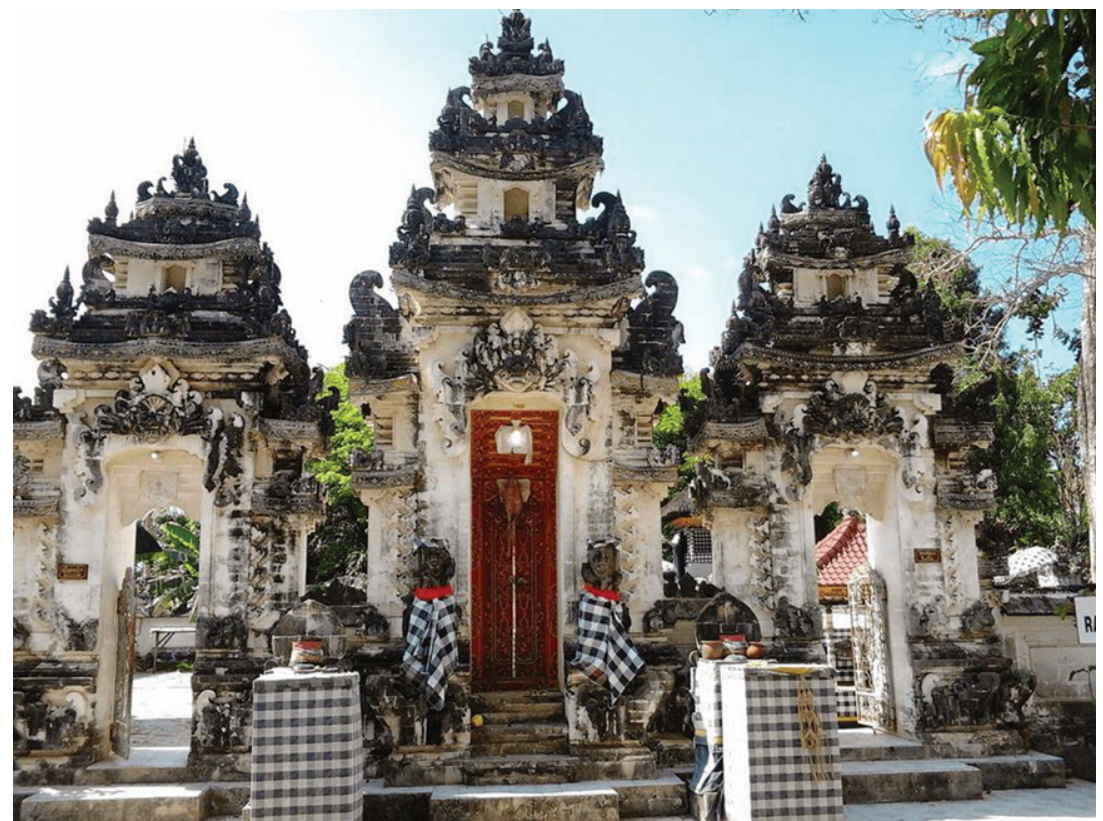

Figure 2. Dalem Ped Temple, Nusa Penida.

years. The figure of Bhatara I Kusumadanta was referred to Lord Ganesha. ${ }^{6}$ The claim is strongly connected to the mythology of the lord Ganesh in the Book of Panggelaran, where He mentioned as Gramdewa, a protective deity of the Village or community. The Ganesha is also worshipped as a god of success and obstacles removal. Besides, In the Book of Ganapati Tattwa states that Sanghyang Ganesha can repel pests and plant diseases, while the Book of Mahanirwana Tantra mentions Lord Ganesha or Bhatara Gana as the master of the harvest and prosperity.?
Some myths, however, claimed that some plagues and diseases could be caused by a powerful human-being after obtained an extraordinary ability. The power enabled the figure to create largescale chaos and bring famine as the figure's will. The Myth of Ratu Gede Macaling, a King of Demons, goblins and evil spirits is a well-known legend that spread in the eastern coast of Bali. The figure is believed to be a mere human. However, after his relentless meditation, Lord Shiva granted him a mythical power, and a boon to lead the demon armies, and to cause plagues, pestilences \& disaster on the Island of Bali. According to the Myth, it is said that he currently resides in his invisible fortress at Dalem Ped Temple, Nusa Penida. What makes him even more feared among the mortal being is the fact that every year, on the sixth month of Saka Calendar system, he owns a privilege to sail with his subordinate to claim souls on the island of Bali.

Another well-known story both in Bali and Eastern java is the story of Calonarang. In the $12^{\text {th }}$ century, the old widow led her followers to spread terror and wreak havoc in the Kediri Kingdom. Calonarang and her followers were prominent in witchcraft and black magic; thus, they caused great terror and nightmare on the Kingdom. Her motive was a disappointment to society since no family dares to take her beautiful daughter Ratna Mangali as a daughter in law, despite her kindness and pure heart. ${ }^{10}$ Meanwhile, there was a story in Bali entitled Ki Balian Batur, who enraged after his daughter was slandered by a madman at the market. The madman was spreading hoax, telling Balian Batur's daughter was selling food with human flesh as dishes. His dismay worsened after the society, without conducting further investigation, harshly rode his daughter while the official did not prevail the justice. In 1700 saka, Ki Balian Batur ordered his students to make a gerubug (plague) in Cau Village, that made Mengwi kingdom should bury their hatchet with Klungkung Empire to overcome the catastrophe.

\section{PLAGUES AND DISEASES IN HISTORY OF BALI}

The society identified Plagues and diseases under several umbrella terms. According to the ancient texts, plagues and diseases were known as Mrana, Gering Agung, Gerubug, Cakbyag, Sakit gede, Bah Bedeg and Sasab. Mrana is a type of infection that may catch plant, animal and human. Gering agung is a contagious disease that often occurs in some period of times. Sometimes, gering agung also refers to a condition when rain does not fall for an extended period. Cakbyag, sakit gede and bah 


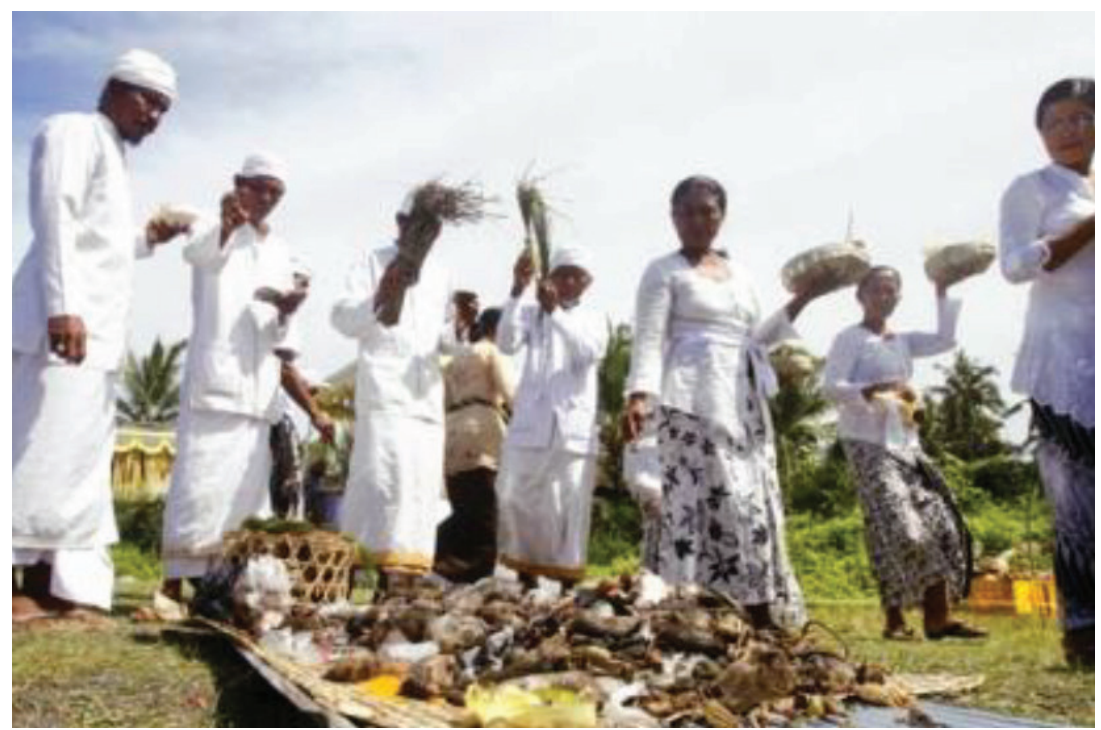

Figure 3. As a symbol of apology, farmers would hold another ritual Ngaben Tikus as their way to apologise and pray for the little soul to reach a higher position in the afterlife. ${ }^{14}$

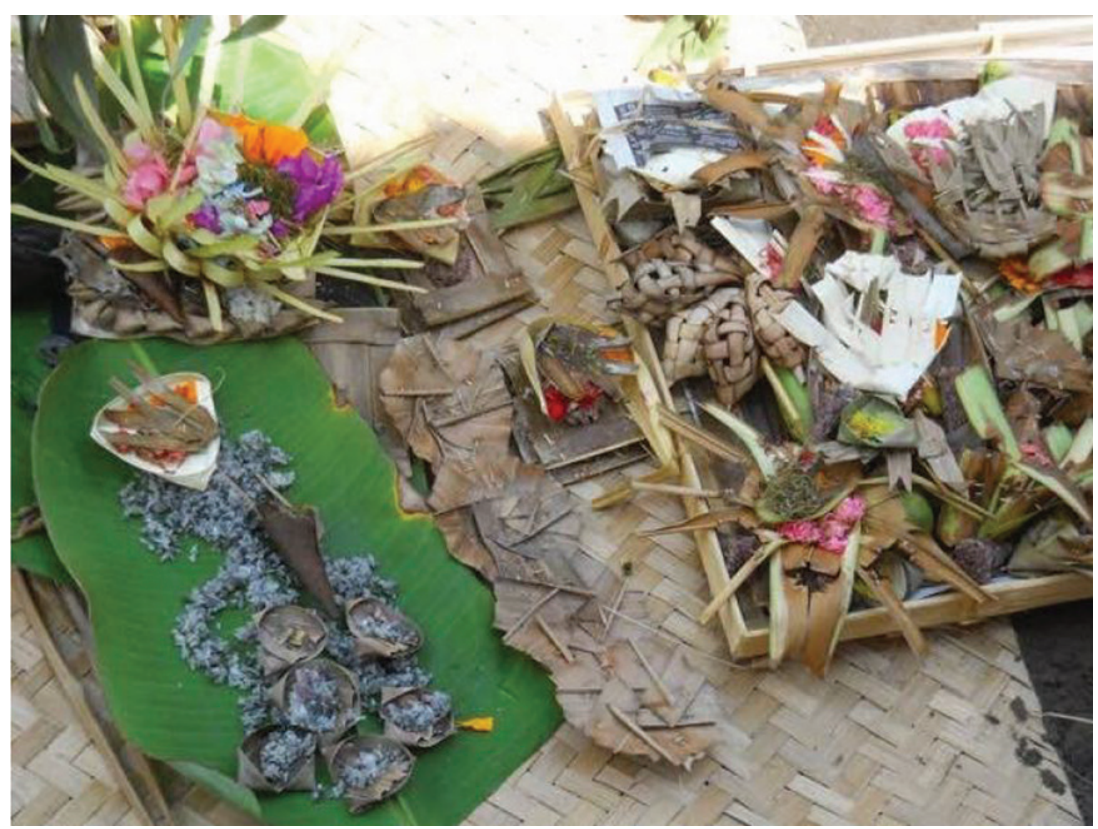

Figure 4. Typical offerings in Sasih Kanem ${ }^{18}$

bedeg are classified under Gerubug term. It was a condition when livestock and society experienced sudden-mass death without any prior symptom. And last is Sasab, a type of deadly contagious fever. ${ }^{12}$

The ancient Balinese civilisation believed that any disease, plague and catastrophe were caused by an influential figure, or related to the cosmic plan. Therefore, their approach to abolishing the problem was by praying to God and ask for an apology. The other resolution was waiting for a mighty figure such as King, priest or sage to help them in facing the disaster. The simple community approach was based on the fact that in the past, they were unaware of any scientific knowledge. Thus, before the $21^{\text {st }}$ century, scientific research to identify or learn the source of disease were not at their disposal. Albeit there was no scientific study in medicine, yet we may find various indigenous herbal medication text that provides information for a particular disease and its remedy. However, the text was shrouded in Myth as well. For instance, an ancient Balinese herbal medication script to overcome cakbyag, Usadha Taru Pramana, even claimed to be passed from Goddess Durga. The knowledge had been transferred to Mpu Kuturan, after he performed deep meditation, asking for God's help. ${ }^{13}$ The text mentioned approximately 202 types of plants could be utilised whenever someone caught by the disease. The ancient texts of medicine are well preserved and keep being learned even by medical practitioner nowadays. Besides Usadha Taru Pramana, there are several popular scripts to be studied by 'Balian' or Balinese shaman to improve their insight about typical local disease and pestilence such as Usadha Buda Kecapi, Usadha Cukil Daki and Usadha Bebai.

\section{HOW SOCIETY COPE WITH THE EVENT}

The old Balinese society was unaware of conducting scientific research to identify the cause of a disease. However, they have an exceptional attitude in treating their surrounding, including to understand any of their misfortune. Take, for example, an old teaching that suggests one should avoid overly complaining or insulting any lousy condition they experience. Or else, it would multiply and consume one's body and mind. The teaching has been actively practised by the farmer, especially when they were facing rat pest in their farms. Not only suggest one should stay in their positive mindset, but the farmer event prays and humbly asked the pest to leave their rice field willingly. Should the rats do not seem to disappear after multiple requests and prays, then they will start to hunt it. Eventually, as a symbol of apology, farmers would hold another ritual Ngaben Tikus as their way to apologise and pray for the little soul to reach a higher position in the afterlife. ${ }^{12}$

Meanwhile, in Dukuh Penaban Village, Karangasem, the local has a sacred dance that is still performed until today as a solution to stop the deadly disease in the past. The dance is called Poleng Canglongleng dance. The dance can only be staged on certain days, such as every full moon on fourth, seventh and tenth month in Balinese calendar, umanis and pahing Kuningan. The dance would be staged in Puseh Dukuh Penaban Temple. The history of the dance was dated back in 1721 Caka, where unstoppable disasters took place. Then, there 
was a whisper to perform a sacred dance. It was said that once the protector deities of the Village were allowed to perform, the misfortune would be gone forever. The community hastily held an offering ceremony, included to perform a sacred dance by a group of a dancer with black-white checkerboard motives (Poleng) costume. Soon after the dance started to perform, miraculously, the plague and disaster instantly vanished. Since that time, the dance becomes a routine schedule that should not be missed..$^{15}$ Others local tradition such as Omedomedan in Banjar Kaja Sesetan, ${ }^{16}$ or Makotekan in Munggu were born after a similar situation in the past. Up to these days, locals believe, should they absent to conduct the rituals, misfortune and sorrow are surely approaching to their Village. ${ }^{17}$

The further ceremony is every Sasih Kanem; The Balinese community hold offerings as a mean to repel and reduce the month's negative atmosphere. The ritual is strongly connected to the Myth of Ratu Gede Mecaling, that regularly docks and visits the island of Bali to collect souls. According to scientific explanation, The sixth month or sasih kanem in Balinese calendar commonly falls between Novembers - December, where monsoon begins to blow from Australia continent to Indonesia archipelago. ${ }^{19}$ The monsoon takes significant change on the island's weather; where heavy rain starts to fall, while some area left dry and humid. Pest such as locus, flies, and mosquitoes begin to breed that eventually leads to diseases. ${ }^{20}$ Today, this scientific reason is widely known by the people in Bali. However, although most Balinese understand the scientific reasons behind the phenomenon, yet they do not dare to completely abandon the Sasih Kanem ritual, which has been long practised before their parents were even born. They believed, to respect the ceremony is equal to respect their ancestor's legacy, as well as to respect their identity.

If we take a closer look, there are countless rituals and ceremony held by Balinese throughout the island. Some of the routines are celebrated every millennium, century, decade, five years, annually, twice a year, every fifteen days and many more depends on the area. ${ }^{21}$ Not to mention that those events are being carried on by individual, family, neighbourhood, Village, regency to district levels, but only for the Hindus. Indeed, the ceremonies are uncountable. The activities well merged to the society and give colours to what we see as daily life on the island of gods or the piece of paradise. The ceremony does not present because of tourism; it is sustainable as a heritage from the old wisdom.

\section{CONCLUSION}

The Myth from ancient Balinese texts helps to provide consultation as well as the perspective of the ancient civilisation in dealing with many unfortunate situations, including plagues and diseases. The mythical story leads to numerous ceremonies being celebrated on the island. The ritual act as an expression of gratitude, apologise, and a moment to self-reflect that humankind is not the only creature that inhabits the universe. The teaching emphasises that the local community is mandatory to take care of their environment, avoid exploiting nature, subsequently as an alarm to the individual to live in humble and responsible. Despite the locals are well adapted to modern technology and received higher education, apparently did not halt the rites. They believed the activities are identity as well as precious treasure from their honourable ancestor.

\section{REFERENCES:}

1. Harari YN. Sapiens: A brief history of humankind. Random House; 2014.

2. Koentjaraningrat. Pengantar ilmu antropologi. Penerbit Rineka Cipta; 1990.

3. Image taken from 'Misteri Kitab Sihir Calonarang'. Anehdidunia[.]com. 2017. Available at URL: https://www. anehdidunia.com/2017/05/misteri-kitab-sihir-calonarang. html

4. Danandjaja J. Cerita rakyat dari Bali. Grasindo; 1993.

5. S Lanus. 'Apakah Bali Kebal Wabah Covid-19?'. Tatkala. 2020. Available at URL: https://tatkala.co/2020/03/21/ apakah-bali-kebal-wabah-covid-19/

6. Atmojo, M.M. Sukarto Karto. 1995. "Parimandala Karaman Jiken Satra." Dalam Proceeding Analisis Hasil Penelitian Arkeologi: Analisis Sumber Tertulis Masa Klasik, 102-110. Jakarta: Departemen Pendidikan dan Kebudayaan.

7. Bagus AA. Gde. 2015.“. In Arca Ganesa Bertangan Delapan Belas Di Pura Pingit Melamba Bunutin, Kintamani, Bangli”. Forum Arkeologi (Vol. 28, pp. 25-34).

8. Image from 'Pura Dalem Ped (Dalem Ped Temple) Nusa Penida Island'. Mynusapenida[dot]com. Available at URL: http://mynusapenida.com/pura-dalem-ped-dalem-pedtemple-nusa-penida-island/

9. Saputra IM. The Mystisim Of Bhairawa Tantra In The Myth Of Ida Ratu Gede Mas Macaling Dalem Nusa In The Balinese Cultural Tradition. Vidyottama Sanatana: International Journal of Hindu Science and Religious Studies. 2019 Jun 1;3(1):39-46.

10. Widayanti IG, Surada IM, Brahman IM. KAJIAN FILOSOFIS LONTAR CALONARANG. Jurnal Penelitian Agama Hindu. 2018 May 28;2(1):274-9.

11. Trijayanti NK, Joni ID, Gelgel NM. FAKTOR-FAKTOR YANG MEMPENGARUHI SIKAP MASYARAKAT DESA PAKRAMAN BATUAN TERHADAP MITOS I GEDE MECALING

12. S Lanus. 'Ajaran Leluhur Bali dalam Menyapa Wabah'. Balipost. 2020. Available at URL: http://www.balipost.com/ news/2020/04/07/114161/Ajaran-Leluhur-Bali-dalamMenyapa...html 
13. Antari NP, Suwantara IP, Cahyaningsih E. The Correlation of Pemogan Community Knowledge about Usada Taru Pramana with the Behaviour of Utilization and Conservation of Herbal Medicine. Majalah Obat Tradisional. 2017;22(3):206-10.

14. Iage from Official Site Kemdikbud 'Mengusir Hama Tikus Melalui Upacara Ngaben Tikus'. 2015. Available at URL: https://kebudayaan.kemdikbud.go.id/bpnbbali/mengusirhama-tikus-melalui-upacara-ngaben-tikus/

15. E Parananda. 'Tari Poleng Canglongleng di Desa Adat Dukuh Penaban Dipercaya Mampu Jinakkan Wabah Penyakit'. Balipost. 2020. Available at URL: http://www. balipost.com/news/2020/03/22/111342/Tari-PolengCanglongleng-di-Desa...html

16. Artiningsih NW. INTERNALISASI NILAI SAKRAL DALAM TRADISI OMED-OMEDAN DI BANJAR KAJA KELURAHAN SESETAN KOTA DENPASAR. Purwadita: Jurnal Agama dan Budaya. 2019 Aug 26;1(2):1-7.

17. Ni Made W. Asal Mula Tari Mekotekan di Desa Munggu Kabupaten Badung. Artikel Bulan September (2011). 2011;2(9):1-
18. Image from Official website of Desa Abiansemal Badung 'Kenapa Perlu Dilaksanakan Upacara Nangluk Merana'. 2019. Available at URL: http://www.desaabiansemal. badungkab.go.id/baca-berita/5963/Kenapa-PerluDilaksanakan-Upacara-Nangluk-Merana.html

19. Purwaputra I. Peramalan Curah Hujan untuk Evaluasi Pola Tanam Berdasarkan Penanggalan Sasih di Bali (Doctoral dissertation, Institut Technology Sepuluh Nopember).

20. NV. 'Netralkan Keramatnya Sasih Kanem'. Nusa Bali. 2017. Available at URL: https://www.nusabali.com/berita/21375/ netralkan-keramatnya-sasih-kanem

21. Suryani IG. Jenis dan hakikat ritual bhuta yadnya pada masyarakat Hindu Bali. Udayana University Press; 2011.

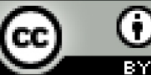

This work is licensed under a Creative Commons Attribution 